\title{
Islet inflammation impairs the pancreatic beta-cell in type 2 diabetes
}

\author{
Donath, M Y ; Böni-Schnetzler, M ; Ellingsgaard, H ; Ehses, J A
}

\begin{abstract}
Onset of Type 2 diabetes occurs when the pancreatic beta-cell fails to adapt to the increased insulin demand caused by insulin resistance. Morphological and therapeutic intervention studies have uncovered an inflammatory process in islets of patients with Type 2 diabetes characterized by the presence of cytokines, immune cells, beta-cell apoptosis, amyloid deposits, and fibrosis. This insulitis is due to a pathological activation of the innate immune system by metabolic stress and governed by IL-1 signaling. We propose that this insulitis contributes to the decrease in beta-cell mass and the impaired insulin secretion observed in patients with Type 2 diabetes.
\end{abstract}

DOI: https://doi.org/10.1152/physiol.00032.2009

Posted at the Zurich Open Repository and Archive, University of Zurich ZORA URL: https://doi.org/10.5167/uzh-26504

Journal Article

Originally published at:

Donath, M Y; Böni-Schnetzler, M; Ellingsgaard, H; Ehses, J A (2009). Islet inflammation impairs the pancreatic beta-cell in type 2 diabetes. Physiology, 24:325-331.

DOI: https://doi.org/10.1152/physiol.00032.2009 


\section{Islet Inflammation Impairs the Pancreatic $\beta$-Cell in Type 2 Diabetes}

Onset of Type 2 diabetes occurs when the pancreatic $\beta$-cell fails to adapt to the increased insulin demand caused by insulin resistance. Morphological and therapeutic intervention studies have uncovered an inflammatory process in islets of patients with Type 2 diabetes characterized by the presence of cytokines, immune cells, $\beta$-cell apoptosis, amyloid deposits, and fibrosis. This insulitis is due to a pathological activation of the innate immune system by metabolic stress and governed by IL-1 signaling. We propose that this insulitis contributes to the decrease in $\beta$-cell mass and the impaired insulin secretion observed in patients with Type 2 diabetes.
Marc Y. Donath, Marianne Böni-Schnetzler, Helga Ellingsgaard, and Jan A. Ehses

Division of Endocrinology, Diabetes, and Nutrition, and Center for Integrated Human Physiology, University Hospital of Zürich, Zürich, Switzerland marc.donath@usz.ch
Major progress has been achieved in our understanding of the pathogenesis of Type 2 diabetes (3, $13,34,52)$. Over-nutrition and inactivity promote insulin resistance. To cope with this increased demand of insulin secretion, the pancreatic islet needs to enhance its secretory activity. In most individuals, such an adaptation does occur during early stages of increased metabolic stress (characterized by over-nutrition). Although successful adaptation of the $\beta$-cell permits maintenance of normal metabolism throughout life in most subjects, this adaptation eventually fails in some individuals, depending on the genetically determined ability of the $\beta$-cell to adapt and the severity of the resistance to insulin. The reasons for this failure to maintain sufficient insulin secretion are a combined decrease in $\beta$-cell mass and defective insulin secretion. Several mechanisms have been proposed to explain this failure, including ER stress, oxidative stress, amyloid deposition, lipotoxicity, and glucotoxicity $(28,33,51,54$, $65)$. Interestingly, all these factors may induce an inflammatory response, whereas some may be the result of the inflammation $(16,17,19,31)$. Initially, an inflammatory response is probably deployed to promote $\beta$-cell repair and regeneration. However, as it becomes chronic, the situation gets complicated by, e.g., the activation of auto-inflammatory processes that may then become deleterious. Interestingly, similar auto-inflammatory processes occur in insulin-sensitive tissues. Therefore, Type 2 diabetes can be considered an auto-inflammatory disease. Consequently, it can be treated by agents blocking this vicious cycle such as IL-1 antagonists, or more downstream by NF- $\kappa \mathrm{B}$ modulation via salsalate or similar compounds $(15,59)$.

In this article, we will review the evidence for insulitis in Type 2 diabetes, the mechanisms inducing this inflammatory process, its physiological and pathological role, and the therapeutic consequences.

\section{Evidence for an Islet Inflammatory Process in $\beta$-Cell Failure During Type 2 Diabetes}

In 1967 it was first proposed that Type 2 diabetes is not solely due to insulin resistance but also to a failure of the insulin producing $\beta$-cell to secrete an adequate amount of insulin (5). Based on numerous investigations, it is now evident that impaired insulin secretion is not only an important etiological factor in the pathogenesis of the disease but also the driving force dictating the dynamics of the disease. Indeed, although insulin resistance is present in all stages from pre-diabetes to overt diabetes, it remains constant in a single individual as long as his or her body weight remains unchanged. In contrast, the onset of diabetes and its progression is largely determined by the progressive failure of the pancreatic islet. At a pre-diabetic stage, insulin production will increase to adapt to the enhanced demand. When this adaptation fails, diabetes occurs. This failure then continues to progress, and affected individuals will require increasing antidiabetic treatment, until eventually all Type 2 diabetics require exogenous insulin to control their glycemia. In an attempt to understand the underlying cause of this progressive failure, several mechanisms have been described. It appears that in all instances they constitute various components of an inflammatory process. The first evidence for an inflammatory process in the pancreatic islet arose from the observation that hyperglycemia induces $\beta$-cell apoptosis (14). By unravelling the underlying mechanism, it turned out that high glucose concentrations induce the Fas receptor, which in turn is upregulated via glucoseinduced IL- $1 \beta$ production $(41,43,44)$. Similarly, recent evidence shows that fatty acids also promote an inflammatory response (Refs. 1, 21; and see below). More downstream, ER stress and oxidative stress also appear linked to inflammatory events. In support of 
insulitis in Type 2 diabetes, elevated numbers of immune cells have been detected in islets of patients with Type 2 diabetes in conjunction with increased levels of cytokines and chemokines $(2,21,53)$. Of note, every animal model of Type 2 diabetes investigated to date displays islet immune cell infiltration $(19,21)$. Furthermore, a strong argument for the occurrence of an inflammatory process in islets is the well described fibrosis observed in tissue sections of patients with Type 2 diabetes, characterized by amyloid deposits. Indeed, fibrosis is a hallmark of the end stage of a chronic inflammatory process. Although the concept of insulitis is recent in Type 2 diabetes, it is well established in Type 1 diabetes and was considered as pathognomonic. Although the precise aetiology of the insulitis in both diabetes types remains to be fully understood, differences certainly exist; for example, Type 1 diabetes is a more autoimmune-mediated process. However, a common final effector pathway seems to be activated in both types of diabetes (17). Keeping in mind that metabolic stress is a more recent threat than viruses or other possible causes of Type 1 diabetes, it is not surprising that islets respond with similar mechanisms developed over their long period of evolution. Of interest is the predominant role of IL$1 \beta$, which is upregulated in islets of patients with both Type 1 and Type 2 diabetes $(2,43,45)$. This master cytokine regulates numerous cytokines and also chemokines (Refs. 12, 20; and see below). Thereby, it contributes to the recruitment of immune cells implementing a broad inflammatory response. Of note is that IL- $1 \beta$ will also induce itself in $\beta$-cells, engendering a vicious cycle (Ref. 2; and see below). Thus insulitis may be considered as an integral component of the pathology observed in Type 2 diabetes, and its dependence on IL-1 supports the concept of an autoinflammatory nature of the disease.

\section{Regulation of IL-1 $\beta$ Expression by Nutrients in Human Islets}

Elevation of circulating nutrients such as glucose and free fatty acids (FFAs) induce an inflammatory process within numerous tissues in the body $(32,68)$. The first demonstration that a high glucose concentration indeed induces IL- $1 \beta$ release was obtained with human islets (43), with similar observations following in rat islets (24), retinal cells (70), and human monocytes (8). Moderately elevated glucose concentrations (11 mM) were sufficient to induce transcriptional activation of IL-1 $\beta$ expression in human islets (2).

More recently, we also found that long-chain FFAs induce several cyto- and chemokines in human and rodent islets (1). Oleate, palmitate and stearate, which are the most abundant FFAs in human nutrition, and hence in the circulation, stimulate IL- $1 \beta$ expression when added individually or as mixtures. Similarly, FFAs induced the IL-1-dependent cyto- and chemokines IL-6 and IL-8 in human islets and CXCL1 (also known as chemokine KC) in mouse islets. These stimulatory effects of FFAs on proinflammatory mediators are not restricted to islet cells but were also observed in numerous other cell types such as muscle (57), macrophage, and adipocyte cell lines $(47,58,60)$, and in coronary artery endothelial cells (62). The combination of FFAs with elevated glucose concentrations further increases IL-1 $\beta$ expression (1) and the release of various cyto- and chemokines (21).

But how do these distinct and "nonspecific" nutrients lead to elevated expression of IL-1 $\beta$ and of IL-1regulated cyto- and chemokines in islets? Some insight was obtained when we examined specific agonists of receptors of the innate immune system, specifically the IL-1/Toll-like receptor (TLR) family (1). Their stimulation typically leads to activation of proinflammatory processes in response to microbial pathogens and cell stressors (49). In human islets, specific TLR2 and TLR4 agonists induce IL-1 $\beta$; however, the strongest inducer of IL- $1 \beta$ expression is IL- $1 \beta$ itself, which increases its own expression by an autostimulatory mechanism. IL-1 $\beta$ auto-stimulation was particularly pronounced in purified $\beta$-cells compared with whole islets, which consist of different cell types (2). Furthermore, it was NF-кB dependent and could be interrupted by blocking the IL-1 receptor with the specific IL-1 receptor antagonist (IL-1Ra) by neutralizing the receptor ligand or by deleting the intracellular receptor docking protein required for signal transduction (Myd88). Using these tools, we could demonstrate that both elevated glucose concentrations and FFAs increase IL-1 $\beta$ expression by promoting IL-1 $\beta$ autostimulation via IL-1 receptor activation. Thus IL-1 $\beta$ auto-stimulation via its receptor plays a pivotal role in the upregulation of intra-islet IL-1 $\beta$ expression provoked by nutrients. Noteworthy, we observed the highest levels of IL-1 receptor I expression in mouse islets and in an insulin-secreting $\beta$-cell line compared with 22 other rodent tissues (1). These data suggest that the pancreatic $\beta$-cell may be exquisitely sensitive to changes in local IL-1 $\beta$ concentration due to its high number of IL-1 receptors $(1,55)$.

Although these findings are compatible with a role for the IL-1 system as an amplifier of pro-inflammatory stimuli in islets, it leaves us with the question of how glucose or FFAs trigger and maintain this process. This is currently an open question, particularly for glucose, whereas for FFAs several mechanisms were postulated. It has been hypothesized that FFAs stimulate pro-inflammatory factors via direct activation of the lipid-sensing TLR2 and TLR4 in various cell types (39). Results with islets from TLR KO mice indeed show that FFA-induced pro-inflammatory factors are partly TLR dependent. Human islets express functional TLR2 and $4(1,64)$, and their activation results in increased expression of IL-1 $\beta$ and various cyto- and chemokines. Again, the TLR2/4 response is further 
amplified by IL- $1 \beta$ auto-stimulation. Thus the IL- 1 system in islets not only amplifies the response to circulating nutrients but also to specific TLR agonists. Intriguingly, it was observed that obese subjects and rodents display elevated levels of circulating gut floraderived endotoxins that could potentially trigger TLRs $(4,7)$, or, alternatively, inflammatory factors derived from other organs could stimulate TLRs in islets. To this end, it was recently shown that serum amyloid A binds to TLR2 (6), which is prominently expressed on purified human and rodent $\beta$-cells (J. Ehses, unpublished data, and Ref. 1). Alternative to TLR stimulation, FFA metabolites such as sphingosines have also been implicated in the induction of a pro-inflammatory response (29).

Overall, we conclude that elevated concentrations of various nutrients such as glucose and FFAs may activate the IL- $1 \beta$ system in pancreatic islets. Probably depending on duration of the exposure and the composition and concentrations of the ambient nutrients, sufficient amounts of IL- $1 \beta$ may be triggered to overcome the protective effect of the naturally occurring IL-1Ra (9), thus activating the potent IL-1 receptor. This auto-stimulation engenders a vicious cycle precipitating a broad inflammatory process, as detailed in the next section (see also Figure 1).

\section{IL-1 is a Master Regulator of Tissue and Islet Inflammation in Type 2 Diabetes}

It has been known for a long time that obesity and Type 2 diabetes are associated with chronic activation of the innate immune system (50). Indeed, this activation appears to be systemic, given the increased levels of circulating cytokines and chemokines correlating with the disease and their potential in predicting Type 2 diabetes onset $(30,61)$. Local tissue inflammation is increasingly recognized in the pathology of both obesity-associated insulin resistance and $\beta$-cell failure in human Type 2 diabetes $(16,68)$. In all cases, this inflammation is characterized by increased tissueinfiltrating macrophages $(21,66)$. Indeed, two independent studies have now shown increased isletassociated CD68+ cells in Type 2 diabetic patients (21, 53). Furthermore, data from laser-captured $\beta$-cells from patients with Type 2 diabetes have indicated increased expression of IL- $1 \beta$ mRNA and chemokines, potentially responsible for this immune cell infiltration $(2,46)$. However, the contribution of IL- 1 in the regulation of this islet inflammatory response in vivo was unknown until recently.

A number of animal models of Type 2 diabetes have now been characterized to various degrees regarding the presence of an islet inflammatory signature, including the GK rat, the high-fat diet (HFD)-fed mouse, the $\mathrm{db} / \mathrm{db}$ mouse, the Psammomys Obesus gerbil, the fatty Zucker rat, and the Cohen rat (19, 21, 40, $67)$. In a number of these models, increased islet IL-1 $\beta$ expression and increased numbers of islet macrophages are an underlying feature. We recently extensively characterized the islet inflammatory process in the GK rat, showing increased islet expression of IL-1 $\beta$ and other pro-inflammatory cytokines (IL-6, TNF $\alpha$ ), increased expression of a number of chemokines (CXCL1/ KC, MCP-1, MIP-1 $\alpha$ ), together with immune cell infiltration in the islet (20). Since an important property of IL- $1 \beta$ in auto-inflammatory diseases is to increase the local expression of chemokines and adhesion molecules (12), we investigated the role of IL-1 in tissue inflammation in the GK rat, with a focus on the pancreatic islet. Elevated IL-1 $\beta$ mRNA levels were found in 2-mo-old GK rat islets and liver, with no increases in skeletal muscle or adipose tissue. To assess the biological impact of this finding, we blocked IL-1 $\beta$ activity with IL-1Ra in vitro and in vivo. IL-1Ra was able to suppress GK islet IL-6 and chemokine secretion (CXLC1/KC, MCP-1, and MIP$1 \alpha$ ) in vitro, indicating that IL- 1 activity is partially responsible for driving GK islet cytokine and chemokine expression. Treatment of GK rats with IL1Ra, administered via either mini-osmotic pumps or subcutaneous injections, reduced fed hyperglycemia over the $4 \mathrm{wk}$ of treatment. This was due to both peripheral and islet anti-inflammatory effects impacting on both insulin sensitivity and $\beta$-cell function in a dose-dependent manner. Indeed, analysis of liver and islet inflammation in high-dose IL-1Ra-treated animals (100 mg/kg day IL-1Ra) indicated reductions in inflammatory markers in both tissues. Specifically in the islet, IL-1Ra reduced islet cytokine and chemokine

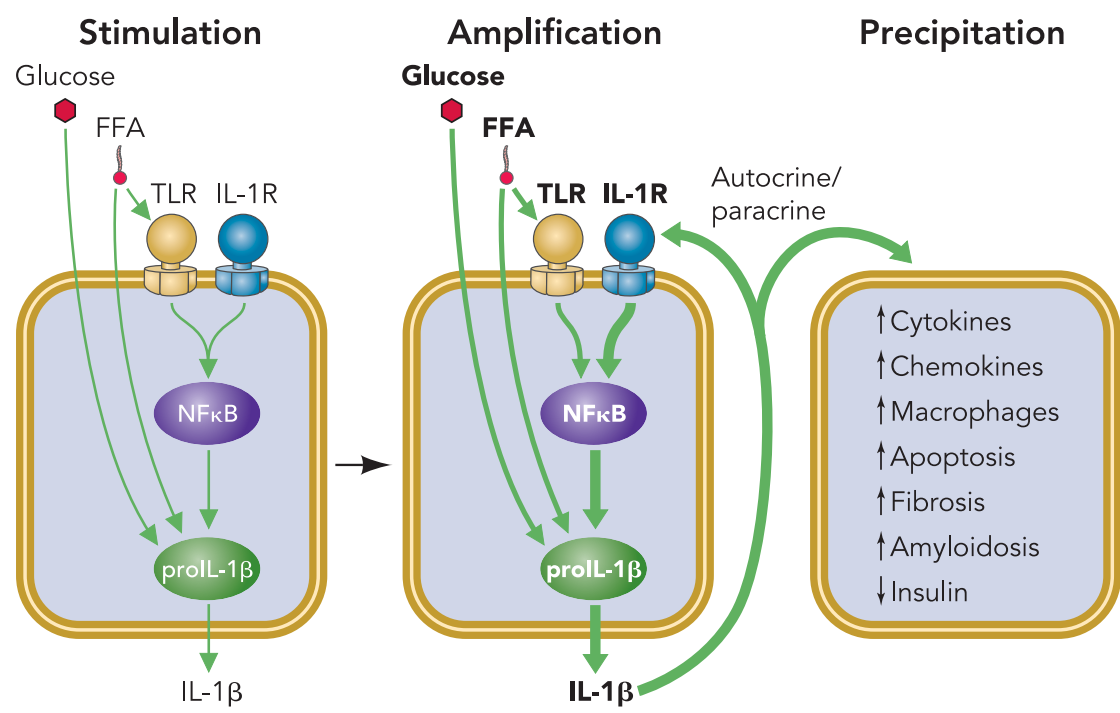

FIGURE 1. Regulation of IL-1 $\beta$ in islets by metabolic stress

Elevated glucose and FFA initially initiate the expression and release of low levels of IL$1 \beta$ (stimulation) required for the adaptive response of islet cells. Continuous or prolonged stimulation with nutrients (metabolic stress) will lead to the activation of the IL$1 \mathrm{RI}$ leading to a further increase of IL-1 $\beta$ by an autostimulatory process and to the production of IL-1-dependent cyto- and chemokines (amplification). Autocrine and paracrine activation will precipitate of a broad inflammatory response including elevated cyto- and chemokine production, attraction of macrophages, apoptosis and amyloidosis, fibrosis, and impaired insulin secretion (precipitation). 
expression, with concomitant decreases in islet macrophage infiltration. Supportive of this reduction in immune cell infiltration, further work has indicated that markers of endothelial cell activation, such as adhesion molecule expression (Vcam1), were also suppressed by IL-1Ra treatment (36). Finally, reduction in islet inflammation correlated with improvements in proinsulin to insulin processing in IL-1Ra-treated animals. Since this IL-1Ra intervention study in the GK rat had minimal effects on $\beta$-cell mass, while improving $\beta$-cell insulin processing and hyperglycemia, we propose that IL-1 $\beta$ drives tissue inflammation, which then impacts on both insulin sensitivity and $\beta$-cell functional mass in Type 2 diabetes. However, this does not exclude some additional direct cytotoxic effects.

\section{“Thus IL-6 regulation of the pancreatic $\alpha$-cell repre-} sents a novel endocrine loop in the regulation of glucose homeostasis."

Interestingly, IL-1Ra treatment of the GK rat also reduced islet IL-1 $\beta$ expression itself, supporting that the auto-stimulatory role of IL-1 $\beta$ in the islet (as described above) plays an important role in the islet inflammatory process in vivo.

In summary, both our in vitro data on human and rodent islets and our in vivo studies on the GK rat support a central role for IL-1 in driving the expression of tissue proinflammatory cytokines and chemokines that subsequently attract immune cells to islets. This inflammatory process leads to impairment of $\beta$-cell function. These data support the concept that Type 2 diabetes is an IL-1-driven auto-inflammatory disease.

\section{IL-6 Regulation of the Pancreatic $\alpha$-Cell}

Pancreatic islet pathology in Type 2 diabetes is characterised not only by reduced $\beta$-cell function and mass but also by increased proportion of $\alpha$-cells relative to $\beta$-cells, together with relative hyperglucagonemia due to $\alpha$-cell dysfunction $(10,63,71)$. Having recently found elevated IL-6 levels in pancreatic islets of models of Type 2 diabetes $(20,21)$, we re-explored its role in the regulation of $\alpha$ - and $\beta$-cells (22).

We confirmed the previously published detrimental effects of IL-6 on insulin secretion in both human and rodent islets in vitro (35). Beyond this, however, we found that the glucagon-producing $\alpha$-cell is a primary target of IL-6. Islet $\alpha$-cells express the IL- 6 receptor and functionally respond to IL-6 kinetically prior to $\beta$-cells. IL-6 was found to increase glucagon secretion under fasting conditions (low glycemia) in isolated islets and when systemically administered in vivo. Furthermore,
IL-6 promoted $\alpha$-cell proliferation and prevented $\alpha$-cell apoptosis due to metabolic stress while exacerbating $\beta$ cell apoptosis. Thus, in contrast to the negative effects on the $\beta$-cell, IL- 6 acts as a growth and survival factor and promotes glucagon secretion in the $\alpha$-cell.

Further studies in vivo supported this hypothesis. For this, we studied the role of IL-6 in the setting of obesity and insulin resistance by feeding wild-type and IL-6 KO mice HFD. Although HFD increased systemic IL-6 levels in wild-type animals, this did not occur in IL-6 KO animals. Most striking, IL-6 KO mice did not show increased $\alpha$-cell mass under these conditions, demonstrating that IL-6 signaling is necessary for the stimulating effect of HFD on $\alpha$-cell mass. Consistent with these $\alpha$-cell-specific findings, IL-6 KO animals displayed reduced fasting glucagon levels relative to wild-type animals on HFD. However, in contrast to the expected improvement in glucose tolerance in these animals, IL$6 \mathrm{KO}$ mice on HFD displayed fed hyperglycemia, impaired glucose tolerance, and impaired glucosestimulated insulin secretion compared with dietmatched wild-type animals. This effect has previously been published using IL-6 KO animals from the same source that we used (11). Since insulin sensitivity was similar among genotypes, the phenotype can be attributed to impaired $\beta$-cell function and suggests a role for the $\alpha$-cell in maintaining $\beta$-cell function in vivo. Indeed, recent reports support this notion. Thus $\alpha$-cell expression of prohormone convertase-1/3 (allowing the $\alpha$-cell to produce GLP-1) or overexpression of the glucagon receptor on $\beta$-cells promotes improved insulin secretion $(25,69)$, thus supporting the hypothesis that the pancreatic $\alpha$-cell can regulate $\beta$-cell function in vivo in a paracrine manner. That $\alpha$-cell mass expansion is an important feature of the pathology of Type 2 diabetes was shown in Type 2 diabetic baboons, in which increased $\alpha$-cell proliferation and mass together with hyperglucagonemia was recently described as part of the islet remodeling process (26).

Thus IL- 6 regulation of the pancreatic $\alpha$-cell represents a novel endocrine loop in the regulation of glucose homeostasis. Although it appears that this mechanism may exist to compensate for impaired $\beta$ cell function in the setting of obesity and/or Type 2 diabetes, it cannot be ignored that elevated IL-6 levels may also drive the relative hyperglucagonemia of diabetic patients. How this pathway contributes to the IL6-mediated effects during physiology [e.g., during exercise, where systemic IL-6 levels are elevated (23)] or during the pathophysiology of obesity and diabetes in humans remains to be examined.

\section{Role of Insulitis in Obesity and Type 2 Diabetes: From Islet Adaptation to Failure}

Inflammation is not in itself a disease but a manifestation of a disease. Initially, it has beneficial effects such 
as preventing spread of infection or promoting regeneration. However, if prolonged or excessive, it may exacerbate disease by tissue destruction. It is likely that, in the case of islet inflammation in Type 2 diabetes, similar phenomena occur. Indeed, the endocrine pancreas has a remarkable capacity to adapt to conditions of increased insulin demand as encountered in obesity and pregnancy by increasing its functional mass. This may be triggered by limited hyperglycemic events that would provoke $\beta$-cell production of very low concentrations of IL-1 $\beta$ followed by Fas upregulation $(41,42)$. At low concentrations of IL-1 $\beta$ and in the presence of FLIP, Fas engagement would lead to $\beta$-cell proliferation and enhanced function via NF- $\mathrm{B}$ and PDX1 (56). Indeed, NF- $\mathrm{BB}$ has been reported to have beneficial effects on both insulin secretion and $\beta$-cell proliferation $(27,48)$. If this response becomes excessive due to prolonged or repetitive exposure to nutrients, this initially adaptive process may become deleterious. IL-1 $\beta$ will then decrease FLIP and Fas engagement and switch to promote deleterious effects. In addition, IL- $1 \beta$ initiates the vicious cycle of inducing itself and promoting an enhanced release of chemokines, which leads to recruitment of macrophages (2). Possibly, these macrophages then produce a high amount of IL-1 $\beta$ (67) and other cytotoxic factors, which then impair the function of the $\beta$-cell. It is important to note that these mechanisms may be responsible for both decreased $\beta$-cell mass and impaired function. Depending on duration and magnitude of the effect as well as the individual regenerative capacity, the functional impairment may predominate over the more definitive decrease in $\beta$-cell mass. Interestingly, such an auto-inflammatory process occurs also in the insulin-sensitive tissues and in end organs such as kidney, eye, and the vasculature. Therefore, tissue inflammation may not only underlie $\beta$-cell failure and insulin resistance but also participate directly in the complications of diabetes, such as nephropathy, retinopathy, and cardiovascular disease.

\section{Clinical Validation and Therapeutic Consequences}

Based on the above-described predominant role of IL$1 \beta$, we initiated clinical trials of IL- 1 antagonism in Type 2 diabetes. In a proof-of-concept study, the naturally occurring antagonist of IL-1 $\beta$, IL-1Ra, was tested in a placebo-controlled study of 70 patients (38). At 13 wk, glycated hemoglobin was significantly improved due to enhanced $\beta$-cell secretory function. Remarkably, the improvement promoted by IL-1 blockade lasted for at least $39 \mathrm{wk}$ following treatment withdrawal (37), thus reflecting the disease-modifying potential of this therapy. Novel therapeutic approaches designed to modulate IL-1 are under development with agents lasting a month or longer (18). Rather than just palliating hyperglycemia, IL-1 antagonism may represent a novel treatment principle directed against the pathogenesis that underlies diabetes mellitus, whereby the progressive decline in functional $\beta$-cell mass could be prevented or even reversed. Due to the auto-inflammatory nature of the whole metabolic syndrome and based on preclinical studies, it is expected that IL-1 antagonism will also enhance insulin sensitivity and prevent complications like blindness, cardiovascular events, and nephropathy. Numerous ongoing clinical studies are based on this assumption.

\section{References}

1. Boni-Schnetzler M, Boller S, Debray S, Bouzakri K, Meier DT, Prazak R, Kerr-Conte J, Pattou F, Ehses JA, Schuit FC, Donath MY. Free fatty acids induce a pro-inflammatory response in islets via the abundantly expressed interleukin-1 receptor I. Endocrinology. In press.

2. Boni-Schnetzler M, Thorne J, Parnaud G, Marselli L, Ehses JA Kerr-Conte J, Pattou F, Halban PA, Weir GC, Donath MY. Increased interleukin (IL)-1beta messenger ribonucleic acid expression in beta-cells of individuals with Type 2 diabetes and regulation of IL-1beta in human islets by glucose and autostimulation. J Clin Endocrinol Metab 93: 4065-4074, 2008.

3. Bonner-Weir S. Islet growth and development in the adult. $J$ Mol Endocrinol 24: 297-302, 2000

4. Cani PD, Amar J, Iglesias MA, Poggi M, Knauf C, Bastelica D, Neyrinck AM, Fava F, Tuohy KM, Chabo C, Waget A, Delmee E, Cousin B, Sulpice T, Chamontin B, Ferrieres J, Tanti JF, Gibson GR, Casteilla L, Delzenne NM, Alessi MC, Burcelin R. Metabolic endotoxemia initiates obesity and insulin resistance. Diabetes 56: 1761-1772, 2007.

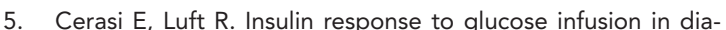
betic and non-diabetic monozygotic twin pairs. Genetic control of insulin response? Acta Endocrinol 55: 330-345, 1967.

6. Cheng N, He R, Tian J, Ye PP, Ye RD. Cutting edge: TLR2 is a functional receptor for acute-phase serum amyloid A. J Immunol 181: 22-26, 2008.

7. Creely SJ, McTernan PG, Kusminski CM, Fisher M, Da Silva NF, Khanolkar M, Evans M, Harte AL, Kumar S. Lipopolysaccharide activates an innate immune system response in human adipose tissue in obesity and Type 2 diabetes. Am J Physiol Endocrinol Metab 292: E740-E747, 2007.

8. Dasu MR, Devaraj $S$, Jialal I. High glucose induces IL-1beta expression in human monocytes: mechanistic insights. Am J Physiol Endocrinol Metab 293: E337-E346, 2007.

9. Dayer-Metroz MD, Wollheim CB, Seckinger P, Dayer JM. A natural interleukin 1 (IL-1) inhibitor counteracts the inhibitory effect of IL-1 on insulin production in cultured rat pancreatic islets. J Autoimmun 2: 163-171, 1989.

10. Deng $S$, Vatamaniuk $M$, Huang $X$, Doliba $N$, Lian MM, Frank A, Velidedeoglu E, Desai NM, Koeberlein B, Wolf B, Barker CF, Naji A, Matschinsky FM, Markmann JF. Structural and functional abnormalities in the islets isolated from Type 2 diabetic subjects. Diabetes 53: 624-632, 2004.

11. Di Gregorio GB, Hensley L, Lu T, Ranganathan G, Kern PA. Lipid and carbohydrate metabolism in mice with a targeted mutation in the IL-6 gene: absence of development of agerelated obesity. Am J Physiol Endocrinol Metab 287: E182-E187, 2004.

12. Dinarello CA. Immunological and inflammatory functions of the interleukin-1 family. Annu Rev Immunol 27: 519-550, 2009.

13. Donath MY, Ehses JA, Maedler K, Schumann DM, Ellingsgaard H, Eppler E, Reinecke M. Mechanisms of betacell death in Type 2 diabetes. Diabetes 54, Suppl 2: S108-S113, 2005.

14. Donath MY, Gross DJ, Cerasi E, Kaiser N. Hyperglycemiainduced beta-cell apoptosis in pancreatic islets of Psammomys obesus during development of diabetes. Diabetes 48: 738-744, 1999.

15. Donath MY, Mandrup-Poulsen T. The use of interleukin-1receptor antagonists in the treatment of diabetes mellitus. Nat Clin Pract Endocrinol Metab 4: 240-241, 2008. 
16. Donath MY, Schumann DM, Faulenbach $M$ Ellingsgaard H, Rütti S, Perren A, Böni-Schnetzler $M$, Ehses JA. Islet inflammation in Type 2 diabetes: from metabolic stress to therapy. Diabetes Care 31: S161-S164, 2008

17. Donath MY, Storling J, Maedler K, MandrupPoulsen T. Inflammatory mediators and islet betacell failure: a link between Type 1 and Type 2 diabetes. J Mol Med 81: 455-470, 2003.

18. Donath MY, Weder C, Whitmore J, Bauer RJ, Der K, Scannon PJ, Dinarello C, Solinger AM. XOMA 052, an anti-IL-1beta antibody, in a double-blind, placebo-controlled, dose escalation study of the safety and pharmacokinetics in patients with Type 2 diabets mellitus: a new approach to therapy. Diabetologia 51: S7, 2008

19. Ehses JA, Ellingsgaard $H$, Boni-Schnetzler $M$, Donath MY. Pancreatic islet inflammation in Type 2 diabetes: from alpha and beta cell compensation to dysfunction. Arch Physiol Biochem 115 240-247, 2009

20. Ehses JA, lacraz G, Giroix MH, Schmidlin F, Coulaud J, Kassis N, Irminger JC, Kergoat $M$ Portha B, Homo-Delarche F, Donath MY. IL1 antagonism reduces hyperglycemia and tissue inflammation in the Type 2 diabetic GK rat. Proc Natl Acad Sci USA 106: 13998-14003, 2009.

21. Ehses JA, Perren A, Eppler E, Ribaux P, Pospisilik $J A$ Maor-Cahn $R$, Gueripel $X$, Ellingsgaard $H$ Schneider MK, Biollaz G, Fontana A, Reinecke M, Homo-Delarche F, Donath MY. Increased number of islet-associated macrophages in Type 2 diabetes. Diabetes 56: 2356-2370, 2007.

22. Ellingsgaard $H$, Ehses JA, Hammar EB, Van Lommel L, Quintens R, Martens G, Kerr-Conte J, Pattou F, Berney T, Pipeleers D, Halban PA, Schuit FC, Donath MY. Interleukin-6 regulates pancreatic alpha-cell mass expansion. Proc Natl Acad Sci USA 105: 13163-13168, 2008.

23. Febbraio MA, Pedersen BK. Muscle-derived interleukin-6: mechanisms for activation and possible biological roles. FASEB J 16: 1335-1347, 2002.

24. Fei $H$, Zhao $B$, Zhao $S$, Wang $Q$. Requirements of calcium fluxes and ERK kinase activation for glucose- and interleukin-1beta-induced beta-cell apoptosis. Mol Cell Biochem 315: 75-84, 2008.

25. Gelling RW, Vuguin PM, Du XQ, Cui L, Romer J, Pederson RA, Leiser $M$, Sorensen $H$, Holst JJ, Fledelius $\mathrm{C}$, Johansen PB, Fleischer N, Mclntosh $\mathrm{CH}$, Nishimura E, Charron MJ. Pancreatic beta-cell overexpression of the glucagon receptor gene results in enhanced beta-cell function and mass. Am J Physiol Endocrinol Metab 297: E695-E707, 2009.

26. Guardado-Mendoza R, Davalli AM, Chavez AO, Hubbard GB, Dick EJ, Majluf-Cruz A, Tene-Perez CE, Goldschmidt L, Hart J, Perego C, Comuzzie AG, Tejero ME, Finzi G, Placidi C, La Rosa S Capella C, Halff G, Gastaldelli A, DeFronzo RA Folli F. Pancreatic islet amyloidosis, beta-cell apoptosis, and alpha-cell proliferation are determinants of islet remodeling in Type-2 diabetic baboons. Proc Natl Acad Sci USA 106: 13992-13997, 2009.

27. Hammar EB, Irminger JC, Rickenbach K, Parnaud G, Ribaux P, Bosco D, Rouiller DG, Halban PA. Activation of NF-kappaB by extracellular matrix is involved in spreading and glucose-stimulated insulin secretion of pancreatic beta cells. J Biol Chem 280: 30630-30637, 2005.

28. Harding HP, Ron D. Endoplasmic reticulum stress and the development of diabetes: a review. Diabetes 51, Suppl 3: S455-S461, 2002.

29. Haversen L, Danielsson KN, Fogelstrand L, Wiklund $O$. Induction of proinflammatory cytokines by long chain saturated fatty acids in human macrophages. Atherosclerosis 202: 382-393, 2009.
30. Herder C, Haastert B, Muller-Scholze S, Koenig W, Thorand B, Holle R, Wichmann HE, Scherbaum WA, Martin S, Kolb H. Association of systemic chemokine concentrations with impaired glucose tolerance and Type 2 diabetes: results from the Cooperative Health Research in the Region of Augsburg Survey S4 (KORA S4). Diabetes 54 Suppl 2: S11-S17, 2005.

31. Hotamisligil GS, Erbay E. Nutrient sensing and inflammation in metabolic diseases. Nat Rev Immunol 8: 923-934, 2008.

32. Hotamisligil GS, Shargill NS, Spiegelman BM. Adipose expression of tumor necrosis factoralpha: direct role in obesity-linked insulin resistance. Science 259: 87-91, 1993.

33. Hull RL, Westermark GT, Westermark P, Kahn SE. Islet amyloid: a critical entity in the pathogenesis of Type 2 diabetes. J Clin Endocrinol Metab 89: 3629-3643, 2004.

34. Kahn BB. Type 2 diabetes: when insulin secretion fails to compensate for insulin resistance. Cell 92: 593-596, 1998

35. Kristiansen OP, Mandrup-Poulsen T. Interleukin-6 and diabetes: the good, the bad, or the indifferent? Diabetes 54, Supp/ 2: S114-S124, 2005.

36. Lacraz G, Giroix MH, Kassis N, Coulaud J, Galinier A, Noll C, Cornut M, Schmidlin F, Paul $\mathrm{JL}$, Janel N, Irminger JC, Kergoat M, Portha B, Donath MY, Ehses JA, Homo-Delarche F. Islet endothelial activation and oxidative stress gene expression is reduced by IL-1Ra treatment in the Type 2 diabetic GK rat. PLoS ONE 4: e6963, 2009

37. Larsen CM, Faulenbach $M$, Vaag $A$, Ehses JA Donath MY, Mandrup-Poulsen T. Sustained effects of interleukin-1-receptor antagonist treatment in Type 2 diabetes mellitus. Diabetes Care 32: 1663-1668, 2009.

38. Larsen $C M$, Faulenbach $M$, Vaag $A$, Volund $A$, Ehses JA, Seifert B, Mandrup-Poulsen T, Donath MY. Interleukin-1-receptor antagonist in Type 2 diabetes mellitus. N Engl J Med 356: 1517-1526, 2007

39. Lee JY, Sohn KH, Rhee SH, Hwang D. Saturated fatty acids, but not unsaturated fatty acids, induce the expression of cyclooxygenase- 2 mediated through Toll-like receptor 4. J Biol Chem 276: 16683-16689, 2001

40. Li X, Zhang L, Meshinchi S, Dias-Leme C, Raffin D, Johnson JD, Treutelaar MK, Burant CF. Islet microvasculature in islet hyperplasia and failure in a model of Type 2 diabetes. Diabetes 55: 2965-2973, 2006.

41. Maedler K, Fontana A, Ris F, Sergeev $P$, Toso C, Oberholzer J, Lehmann R, Bachmann F, Tasinato A, Spinas GA, Halban PA, Donath MY. FLIP switches Fas-mediated glucose signaling in human pancreatic $B$ cells from apoptosis to cell replication. Proc Natl Acad Sci USA 99: 8236-8241, 2002.

42. Maedler K, Schumann DM, Sauter N, Ellingsgaard $\mathrm{H}$, Bosco D, Baertschiger R, Iwakura Y, Oberholzer J, Wollheim CB, Gauthier BR, Donath MY. Low concentration of interleukin-1beta induces FLICEinhibitory protein-mediated beta-cell proliferation in human pancreatic islets. Diabetes 55 : 2713-2722, 2006

43. Maedler K, Sergeev $P$, Ris F, Oberholzer J, JollerJemelka HI, Spinas GA, Kaiser N, Halban PA, Donath MY. Glucose-induced beta-cell production of interleukin-1beta contributes to glucotoxicity in human pancreatic islets. J Clin Invest 110: $851-860,2002$

44. Maedler K, Spinas GA, Lehmann R, Sergeev $P$, Weber M, Fontana A, Kaiser N, Donath MY Glucose induces beta-cell apoptosis via upregulation of the Fas-receptor in human islets. Diabetes 50: 1683-1690, 2001.

45. Mandrup-Poulsen T. The role of interleukin-1 in the pathogenesis of IDDM. Diabetologia 39: 1005-1029, 1996.
46. Marselli L, Sgroi DC, Thorne J, Dahiya S, Torri S, Omer A, Del Prato S, Towia , Otu HH, Sharma A, Bonner-Weir S, Marchetti P, Weir GC. Evidence of inflammatory markers in beta cells of Type 2 diabetic subjects. Diabetologia 50: S178, 2007

47. Nguyen $M T$, Favelyukis $S$, Nguyen $A K$, Reichart $D$ Scott PA, Jenn A, Liu-Bryan R, Glass CK, Neels JG, Olefsky JM. A subpopulation of macrophages infiltrates hypertrophic adipose tissue and is activated by free fatty acids via Toll-like receptors 2 and 4 and JNK-dependent pathways. J Biol Chem 282: 35279-35292, 2007

48. Norlin $\mathrm{S}$, Ahlgren $U$, Edlund $\mathrm{H}$. Nuclear factorkappaB activity in beta-cells is required for glucose-stimulated insulin secretion. Diabetes 54 125-132, 2005.

49. O'Neill LA. The interleukin-1 receptor/Toll-like receptor superfamily: 10 years of progress. Immunol Rev 226: 10-18, 2008.

50. Pickup JC, Mattock MB, Chusney GD, Burt D NIDDM as a disease of the innate immune system: association of acute- phase reactants and interleukin-6 with metabolic syndrome X. Diabetologia 40: 1286-1292, 1997.

51. Prentki M, Nolan CJ. Islet beta cell failure in Type 2 diabetes. J Clin Invest 116: 1802-1812, 2006.

52. Rhodes CJ. Type 2 diabetes-a matter of beta-cell life and death? Science 307: 380-384, 2005.

53. Richardson SJ, Willcox A, Bone AJ, Foulis AK, Morgan NG. Islet-associated macrophages in Type 2 diabetes. Diabetologia 52: 1686-1688, 2009.

54. Robertson RP, Harmon J, Tran PO, Poitout V. Betacell glucose toxicity, lipotoxicity, and chronic oxidative stress in Type 2 diabetes. Diabetes 53 Suppl 1: S119-S124, 2004.

55. Scarim AL, Arnush M, Hill JR, Marshall CA Baldwin A, McDaniel ML, Corbett JA. Evidence for the presence of type I IL-1 receptors on betacells of islets of Langerhans. Biochim Biophys Acta 1361: 313-320, 1997

56. Schumann DM, Maedler K, Franklin I, Konrad D, Storling J, Boni-Schnetzler M, Gjinovci A, Kurre MO, Gauthier BR, Bosco D, Andres A, Berney T, Greter M, Becher B, Chervonsky AV, Halban PA, Mandrup-Poulsen T, Wollheim CB, Donath MY The Fas pathway is involved in pancreatic beta cell secretory function. Proc Natl Acad Sci USA 104 2861-2866, 2007

57. Senn JJ. Toll-like receptor-2 is essential for the development of palmitate-induced insulin resistance in myotubes. $J$ Biol Chem 281 . 26865-26875, 2006

58. Shi $\mathrm{H}$, Kokoeva MV, Inouye $\mathrm{K}$, Tzameli I, Yin $\mathrm{H}$ Flier JS. TLR4 links innate immunity and fatty acidinduced insulin resistance. J Clin Invest 116: 3015-3025, 2006.

59. Shoelson SE, Goldfine AB. Getting away from glucose: fanning the flames of obesity-induced inflammation. Nat Med 15: 373-374, 2009.

60. Song MJ, Kim KH, Yoon JM, Kim JB. Activation of Toll-like receptor 4 is associated with insulin resistance in adipocytes. Biochem Biophys Res Commun 346: 739-745, 2006.

61. Spranger J, Kroke A, Mohlig M, Hoffmann K Bergmann MM, Ristow M, Boeing $\mathrm{H}$, Pfeiffer AF. Inflammatory cytokines and the risk to develop Type 2 diabetes: results of the prospective population-based European Prospective Investigation into Cancer and Nutrition (EPIC)-Potsdam Study. Diabetes 52: 812-817, 2003.

62. Staiger $H$, Staiger $K$, Stefan N, Wahl HG, Machicao F, Kellerer M, Haring HU. Palmitateinduced interleukin-6 expression in human coronary artery endothelial cells. Diabetes 53 : 3209-3216, 2004 
63. Unger RH, Orci L. The essential role of glucagon in the pathogenesis of diabetes mellitus. Lancet 1: $14-16,1975$.

64. Vives-Pi M, Somoza N, Fernandez-Alvarez J, Vargas F, Caro P, Alba A, Gomis R, Labeta MO Pujol-Borrell R. Evidence of expression of endotoxin receptors CD14, toll-like receptors TLR4 and TLR2 and associated molecule MD-2 and of sensitivity to endotoxin (LPS) in islet beta cells. Clin Exp Immunol 133: 208-218, 2003.

65. Weir GC, Bonner-Weir S. Five stages of evolving beta-cell dysfunction during progression to diabetes. Diabetes 53, Suppl 3: S16-S21, 2004.
66. Weisberg SP, McCann D, Desai M, Rosenbaum M, Leibel RL, Ferrante AW Jr. Obesity is associated with macrophage accumulation in adipose tissue. J Clin Invest 112: 1796-1808, 2003.

67. Weksler-Zangen $S$, Raz I, Lenzen $S$, Jorns $A$, Ehrenfeld S, Amir G, Oprescu A, Yagil Y, Yagil C, Zangen DH, Kaiser N. Impaired glucose-stimulated insulin secretion is coupled with exocrine pancreatic lesions in the Cohen diabetic rat. Diabetes 57: 279-287, 2008.

68. Wellen KE, Hotamisligil GS. Inflammation, stress, diabetes. J Clin Invest 115: 1111-1119, 2005.

69. Wideman RD, Yu IL, Webber TD, Verchere CB, Johnson JD, Cheung AT, Kieffer TJ. Improving function and survival of pancreatic islets by endogenous production of glucagon-like peptide 1 (GLP-1). Proc Natl Acad Sci USA 103: 13468-13473, 2006.
70. Yego EC, Vincent JA, Sarthy V, Busik JV, Mohr S. Differential regulation of high glucose-induced glyceraldehyde-3-phosphate dehydrogenase nuclear accumulation in Muller cells by IL-1beta and IL-6. Invest Ophthalmol Vis Sci 50: 1920-1928, 2009.

71. Yoon $\mathrm{KH}, \mathrm{Ko} \mathrm{SH}$, Cho JH, Lee JM, Ahn YB, Song $\mathrm{KH}$, Yoo SJ, Kang MI, Cha BY, Lee KW, Son HY, Kang SK, Kim HS, Lee IK, Bonner-Weir S. Selective beta-cell loss and alpha-cell expansion in patients with Type 2 diabetes mellitus in Korea. $\mathrm{J}$ Clin Endocrinol Metab 88: 2300-2308, 2003. 